\title{
DEVELOPMENT OF SUCCESSIVE CAMBIA AND STRUCTURE OF SECONDARY XYLEM OF IPOMOEA OBSCURA (CONVOLVULACEAE)
}

\author{
Kishore S. Rajput, Bharat D. Chaudhary \& Vidya S. Patil
}

\begin{abstract}
Stems of Ipomoea obscura Ker Gawl., increase in thickness by forming multiple rings of cambia. Stems 5-6 mm thick produce parenchymatous derivatives which divide repeatedly to form small arcs of cambium. Several such small arcs initiate simultaneously and form a ring of small cambial arcs. After the formation of a few xylem and phloem elements, all these arcs are interconnected by transdifferentiation of parenchyma cells present between the cambial arcs and constitute a complete cambial cylinder. This newly formed cambium is functionally bidirectional: earlier- formed arcs produce xylem centripetally and phloem centrifugally, while later-formed segments exclusively produce thin-walled parenchyma cells on either side. Young stems are circular in cross section but as stem thickness increases they become oval to elliptic or lobed and dumbbell-shaped. Xylem rays are mostly uni- or biseriate and thin-walled, but multiseriate rays characteristic for a climbing habit are observed occasionally. In thick stems, the marginal ray parenchyma in most of the samples becomes meristematic and develops ray cambia which exclusively produce sieve elements. Similarly, parenchyma cells produced from later-formed cambial segments give rise to several irregularly oriented vascular bundles. The secondary xylem is diffuse porous, with indistinct growth rings and is composed of fibriform and wider vessels, fibres, and axial and ray parenchyma cells, while phloem consists of sieve elements, companion cells, and axial and ray parenchyma cells.
\end{abstract}

Key words: Anatomy, cambial variant, Convolvulaceae, multiple cambia, secondary xylem, vines

Kishore S. Rajput, Bharat D. Chaudhary \& Vidya S. Patil, Department of Botany, Faculty of Science, The Maharaja Sayajirao University of Baroda, Vadodara-390002 India; e-mail: ks.rajput15@yahoo.com; patilvidya14@gmail.com

\section{INTRODUCTION}

Ipomoea L. is the largest genus of the Convolvulaceae. Most Ipomoea are vines, but many, such as I. carnea and members of the I. arborescens complex, are self-supporting and have lost the habit of circumnutation (McDonald 1992a, b). Many Ipomoea taxa are used in traditional medicine (Singh et al. 2004; Prasad et al. 2005; Mungole et al. 2010; Meira et al. 2012). Their action is attributed to a large range of bioactive compounds (Meira et al. 2012).

Different species of Ipomoea are characterized by the presence of successive cambia and inter- and intraxylary phloem (Hallier 1893; Pfeiffer 1926; Lowell \& Lukansky 1990; Carlquist \& Hanson 1991; McDonald 1992b; Rajput et al. 2008, Patil et al. 2009). In studies of Ipomoea species, Hallier (1893) gave the first detailed descriptions of anatomy and patterns of secondary growth in the Convolvulaceae. Hallier's work was extended by
Pfeiffer (1926), who documented additional and known types of anomalous secondary growth in Ipomoea. This form of growth was reported to occur in other genera such as Argyreia Lour, Convolvulus L., Maripa Aubl., Neuropeltis Wall. and Rivea Choisy (McDonald 1992b). In the literature there is no information on the pattern of secondary growth and detailed structure of secondary xylem in Ipomoea obscura Ker Gawl. Here we characterize the development of successive cambia and the structure of secondary xylem in this species.

\section{MATERIALS AND METHODS}

Samples measuring 3-20 mm thick and 40-60 $\mathrm{mm}$ in length were collected from main stems of Ipomoea obscura growing at Bhorkheda (Dhule Dist., Maharashtra State). Eight to ten segments each were collected from the base (30 $\mathrm{cm}$ above the ground), middle and apical portions of the stem. Immediately after collection, the 
samples were fixed in FAA (Berlyn \& Miksche 1976) and placed in $70 \%$ alcohol after $12 \mathrm{~h}$ for further processing and storage. The samples were cut into smaller pieces $(8-10 \mathrm{~mm})$ and processed by routine paraffin embedding (Johansen 1940). Thick stems were sectioned directly on a sliding microtome. Transverse, radial and tangential longitudinal sections $12-15 \mu \mathrm{m}$ thick were stained with safranin-fast green (Johansen 1940). Slides were dehydrated through an ethanol xylene series and mounted in DPX.

To obtain the length and width of vessel elements and xylem fibres, small pieces of xylem adjacent to the outermost cambium ring were macerated with Jeffery's fluid (Berlyn \& Miksche 1976) at $55-60^{\circ} \mathrm{C}$ for 8-12 h, then stained with ethanolic solution of safranin. Length and width of the sieve tube elements were measured directly from the tangential longitudinal sections. Means and standard deviations were obtained from thirty random measurements for each cell type. Important results were photographed with a Leica DME 2000 trinocular research microscope. Wood descriptions follow the IAWA Committee guidelines (Wheeler et al.1989) and Carlquist (2001).

\section{RESULTS}

\section{STEM MORPHOLOGY AND ANATOMY}

In cross section, young stems are oval to circular in outline, as the stem increases in thickness, however; eccentric activity of the cambium and unequal deposition of secondary xylem alters the outline conformation of the stem, which can vary in cross section from oval to elliptic, or lobed or dumbbell-shaped (Fig. 1A-C). The young stem is enclosed by a single-layered epidermis made up of barrel-shaped cells lined with thin cuticle on the outer side. A 2-3-cell-layered hypodermis is present beneath the epidermis. The cortex is composed of thin-walled parenchyma cells with irregularly distributed mucilaginous canals within it. After primary growth, several conjoint, collateral vascular bundles are interconnected by interfascicular cambium to form a complete cambial cylinder.

\section{DEVELOPMENT OF SUCCESSIVE CAMBIA}

The first ring of vascular cambium ceases to divide after producing 3-4 mm of secondary xylem, and a new ring of successive cambium ensues from the parenchyma cells (Fig. 1D, E) as small segments (Fig. 1F) that do not form a continuous ring (Fig. 2A). These segments produce secondary xylem centripetally and secondary phloem centrifugally, giving the appearance of vascular bundles (Fig. 1F). Gradually these segments spread tangentially and form a continuous ring of cambium but adjacent segments become separated by thin-walled parenchymatous multicellular rays (Fig. 2A, B). Successive rings of cambia are formed from the parenchyma cells located outside the phloem produced by previous cambium (Fig. 2C).

\section{STRUCTURE OF SECONDARY XYLEM AND PHLOEM}

Thick stems were composed of 3-4 successive rings of xylem alternating with phloem rings. The first ring of xylem formed by normal cambium was continuous with mostly uni- or biseriate rays (Fig. 2B, D). The secondary xylem produced by successive cambia form discontinuous rings and is separated by wide rays which are broader towards the pith and narrower towards the periphery (Fig. 2A, B). The secondary xylem is diffuse porous, with indistinct growth rings, and is composed of vessels (both wider and fibriform), fibres, and axial and ray parenchyma cells. Wider vessels are mostly solitary (Fig. 2D); radial, tangential or diagonal multiples of 2-3 vessels were observed occasionally). The wider vessel elements were 272-378 ( \pm 9.14$) \mu \mathrm{m}$ long and 175-253 $( \pm 4.23) \mu \mathrm{m}$ wide, and fibriform vessel elements were 562-875 $( \pm 7.34) \mu \mathrm{m}$ long and $32-58( \pm 0.84) \mu \mathrm{m}$ in tangential diameter. Xylem fibres were 1137-1271 $( \pm 9.42) \mu \mathrm{m}$ long and nonseptate with simple pits on their radial walls. Secondary phloem is composed of sieve tube elements, companion cells, axial and ray parenchyma cells. Sieve tube elements were 250-327 ( \pm 3.18$) \mu \mathrm{m}$ long.

\section{DEVELOPMENT OF RAY CAMBIUM}

In thick stems the marginal cells of multiseriate rays become meristematic and undergo repeated divisions to form ray cambium (Figs 2E, 3A). In cross section these cambial segments were situated opposite each other; the sieve tube elements 

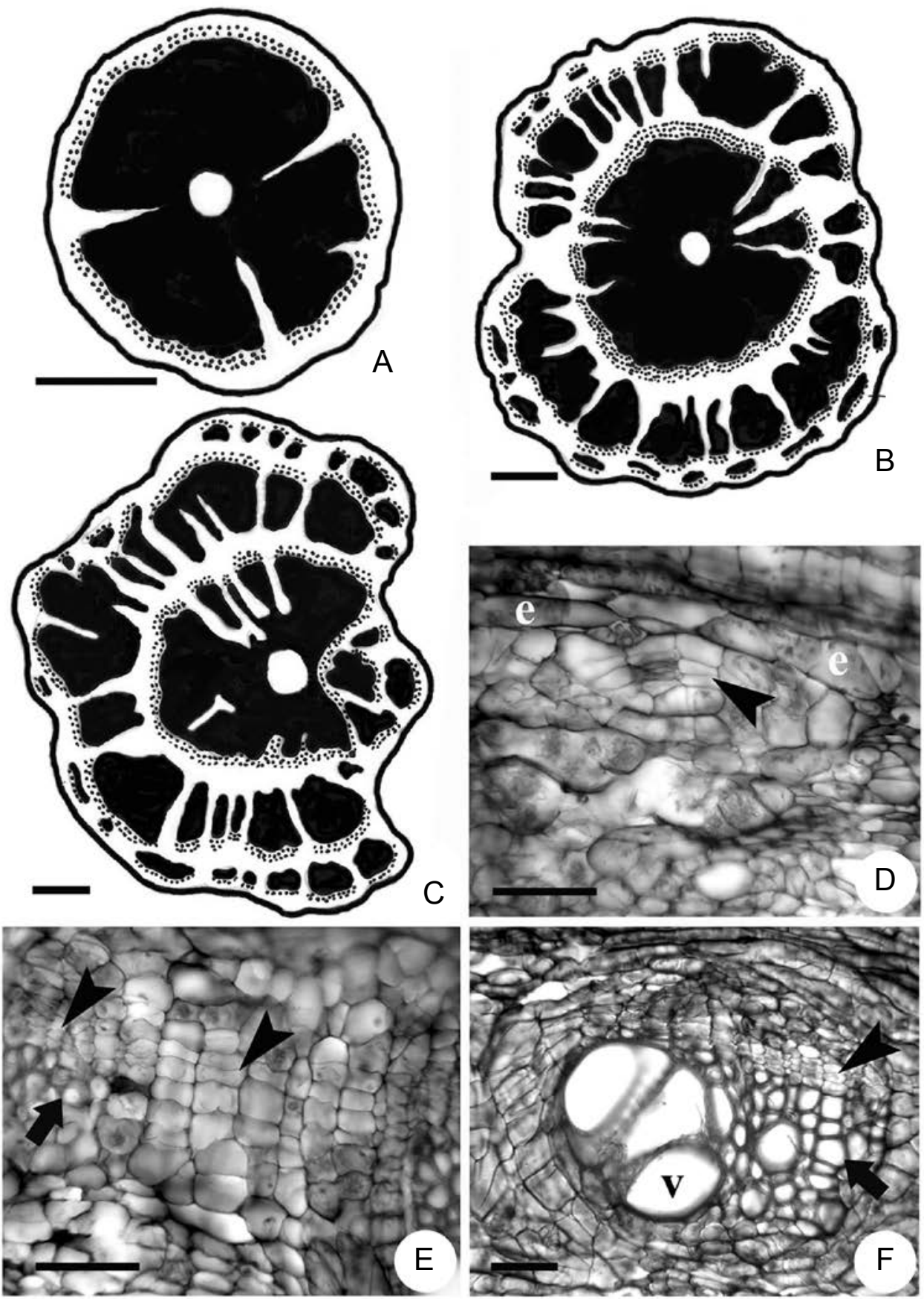

Fig. 1. Schematic diagram (A-C) and transverse view of Ipomoea obscura Ker Gawl. stem. A-C - Stem conformation in crosssectional view showing stem morphology and number of successive cambia. D - Initiation of periclinal divisions in parenchyma cells (arrowhead), e - endodermis. E - Newly developing cambium (arrowheads). Arrow indicates recently formed xylem elements. F - Differentiation of xylem from small arc of cambium (arrowhead) appears like a vascular bundle. Arrow indicates thick-walled xylem. $\mathrm{v}$ - vessel. Scale bars: A \& B $=1.5 \mathrm{~mm} ; \mathrm{C}=2 \mathrm{~mm}$; D-F $=75 \mu \mathrm{m}$. 

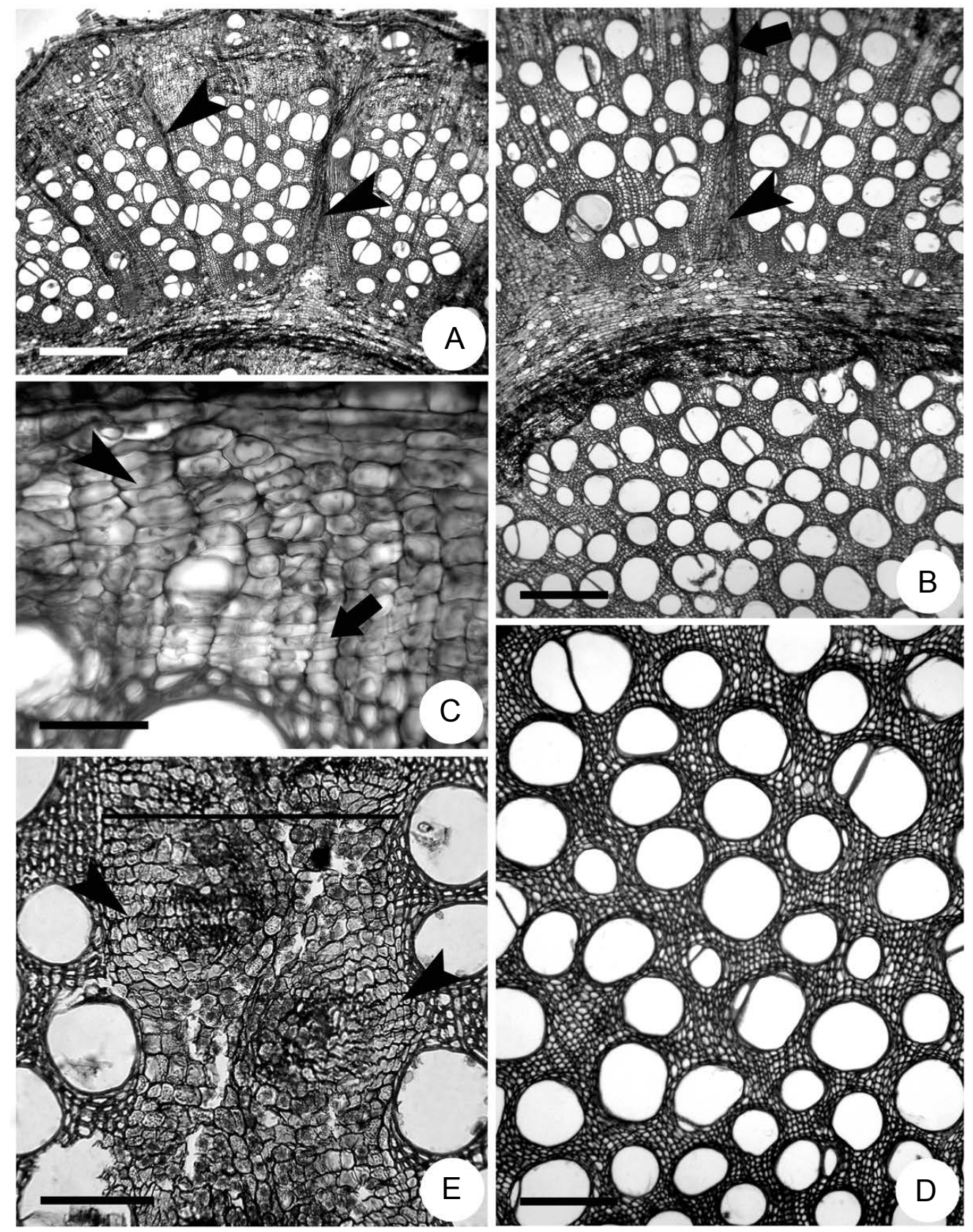

Fig. 2. Transverse view of stem showing structure of xylem (A, B, D) and development of successive cambium (C) and ray cambium (E) in Ipomoea obscura Ker Gawl. A - Secondary xylem produced by successive cambium. Note that thick-walled xylem derivatives are separated by wide rays (arrowheads). B - Xylem rays produced by every successive cambium are wider in the beginning (arrowhead) and gradually narrow (arrow). C - Origin of new cambial segment (arrowhead) outside the phloem produced by previous cambium (arrow). D - Structure of xylem produced by first ring of vascular cambium. E - Origin of ray cambium (arrowheads) from marginal ray cells of wider rays. Dark line shows width of wider ray. Scale bars: A \& B: $=300 \mu \mathrm{m}$; $\mathrm{C}=75 \mu \mathrm{m} ; \mathrm{D} \& \mathrm{E}=150 \mu \mathrm{m}$ 

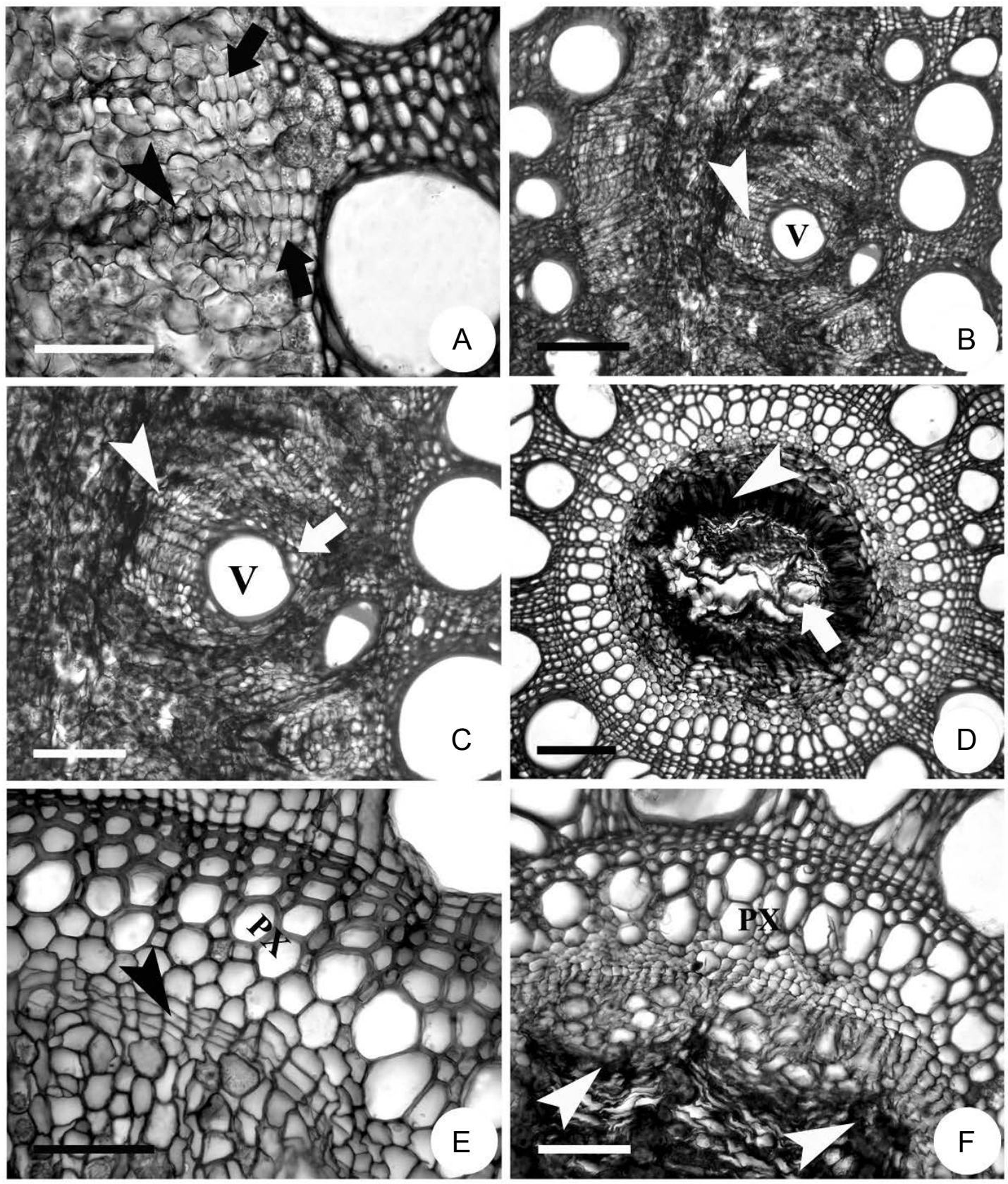

Fig. 3. Transverse view of stem showing ray cambium (A-C) pith (D) and internal cambium (E \& F) in Ipomoea obscura Ker Gawl. A - Enlargement of Figure 2E showing ray cambium (arrows). Arrowhead shows sieve elements produced by ray cambium. B - Bidirectional activity of ray cambium (arrowhead) showing one of the large vessels (v) and a few xylem fibres. C - Enlarged vie of Figure 3B showing vessel (V) and xylem fibres (arrow) and phloem (arrowhead) produced by ray cambium. D - Central portion of stem showing pith with crushed nonconductive internal phloem (arrowhead) and degrading pith cells (arrow). E - Well developed internal cambium (arrowhead) in 8-10 mm thick stem. PX = Primary xylem. F - Pith portion of 15-16 mm thick stem. Arrowheads indicate crushed nonconductive internal phloem. PX $=$ Primary xylem. Scale bars: A, C-F $=100 \mu \mathrm{m} ; \mathrm{B}=300 \mu \mathrm{m}$. 
formed by the two cambia meet in the middle of the ray (Fig. 2E). Initially the ray cambia are unidirectional and form only sieve tube elements, but in later stages of secondary growth they become bidirectional to form xylem and phloem on either side (Fig. 3B). In cross section the sieve tube elements produced by ray cambia are oval to circular in outline, with a simple sieve plate slightly oblique to transverse end walls. Each sieve tube element is associated with small companion cells at its corner. Similarly to external phloem, nonfunctional sieve elements also show heavy accumulation of callose, followed by its obliteration.

\section{DEVELOPMENT OF INTERNAL PHLOEM}

Strands of internal phloem are observed on the inner margin of the pith simultaneously with inception of procambium. As secondary growth proceeds, additional strands of internal phloem develop from the perimedullary parenchyma cells, while earlier-formed nonconductive sieve elements degrade (Fig. 3C). In thick stems the marginal pith cells become meristematic and form internal cambium arcs which are 2-3 cells wide (Fig. 3D, E). These arcs of internal cambium are functionally unidirectional and exclusively produce sieve elements centripetally (Fig. 3E). Most of the pith cells collapse and subsequently degrade (Fig. 3D, F).

\section{DisCUSSION}

Vines differ from trees and shrubs in a number of characteristics, the most remarkable of which involve the mechanical properties of the stem (Isnard et al. 2003, 2009). These mechanical properties of wood have evolved to adapt to the climbing habit. In cross section the stems of climbing species usually develop different outline conformations: lobed (Securidaca rivinifolia A. St.-Hil., Dolichos lablab L.), flattened [Bauhinia surinamensis Amshoff, Rhynchosia phaseoloides (Sw.) DC.], triangular (Serjania communis Cambess, S. lethalis A. St.-Hil.) or cruciform, as in Senegalia pedicellata (Benth.) Seigler \& Ebinger. In I. obscura the stems are round in circumference in the early stages of secondary growth but later become irregular due to unequal deposition of secondary xylem and the formation of successive cambia. These changes in stem form may be the product of a single vascular cambium (Carlquist 2001), or the result of eccentric growth of successive cambia as observed in some members of Menispermaceae (Jacques \& De Franceschi 2007) and Fabaceae (Rajput et al. 2012).

Stem diameter in members of the Convolvulaceae increases by the formation of concentric rings of successive cambia (Metcalfe \& Chalk 1950; Lowell \& Lucansky 1986; Carlquist \& Hanson 1991; McDonald 1992a, b; Rajput et al. 2008; Terrazas et al. 2011). According to the available literature the first successive ring of cambium originates from parenchyma cells located outside the phloem produced by previous cambium (Lowell \& Lucansky 1986, 1990; Rajput et al. 2008; Trazzas et al. 2011). In the present study we observed the first successive ring of cambium originating from pericycle derivatives, followed by further cambium development from parenchyma cells external to the phloem produced by previous cambium.

Besides successive cambia, the occurrence of included and internal phloem is characteristic for the family Convolvulaceae (Lowell \& Lucansky 1986, 1990; Carlquist \& Hanson 1991; McDonald 1992; Rajput et al. 2008; Terrazas et al. 2011). Primary internal phloem in I. obscura develops concomitantly with procambium, while additional internal phloem is added later on by internal cambium that develops from perimedullary cells. Development of internal cambium is not observed frequently but its occurrence in different species of Ipomoea has been reported (Fukuda 1967; Carlquist \& Hanson 1991; McDonald 1992b; Rajput et al. 2008; Patil et al. 2009; Terrazas et al. 2011).

As secondary growth progresses, the marginal ray parenchyma of wider rays become meristematic and form ray cambium. Here we gave the first report of ray cambia in Convolvulaceae; initially they are unidirectional and produce only phloem elements but later become bidirectional and produce xylem elements on either side.

The secondary xylem of I. obscura is similar to that of other lignescent vines of Ipomoea (Lowell \& Lucansky 1986, 1990; Carlquist \& Hanson 1991; McDonald 1992b; Rajput et al. 2008; Terrazas et al. 2011). The occurrence of fibriform 
vessels along with wider vessels in Convolvulaceae is common and said to be associated with the climbing habit of the species.

ACKNOWLedgements. We thank the anonymous reviewers for their useful suggestions. Funding for this work was provided by the Science and Engineering Research Board (SERB) under the Department of Science and Technology (DST) of the Government of India, and by the University Grants Commission, New Delhi.

\section{REFERENCES}

Berlyn G. P. \& MiKsche J. P. 1976. Botanical microtechnique and cytochemistry. The Iowa State University Press, Ames, Iowa.

CARLQUist S. 2001. Comparative wood anatomy: Systematic, ecological and evolutionary aspects of dicotyledon wood. Springer, Berlin, Heidelberg.

Carlquist S. \& Hanson M. A. 1991. Wood and stem anatomy of Convolvulaceae: A survey. Aliso 13: 51-94.

FUKUDA Y. 1967. Anatomical study of the internal phloem in the stems of dicotyledons, with special reference to its histogenesis. J. Fac. Sci. Univ. Tokyo, Sect. 3, Bot. 9: 313-375.

Hallier H. 1893. Versuch einer naturlichen Gliederung der Convolvulaceen auf morphologisher und anatomischer Grundlage. Bot. Jahrb. Syst. 16: 453-591.

ISNARD S., Rowe N. P. \& SPECK T. 2003. Growth habit and mechanical architecture of the sand dune-adapted climber Clematis flammula var. maritima L. Ann. Bot. 91: 407-417.

Isnard S., Cobb A. R., Holbrook N. M., Zwieniecki M. A. \& Dumais J. 2009. Tensioning the helix: a mechanism for the force generation in twining plants. Proc. R. Soc. B. 276: 2643-2650.

Jacques F. M. B. \& De Franceschi D. 2007. Menispermaceae wood anatomy and cambial variants. I.A.W.A. J. 28: $139-172$.

Johansen D. A. 1940. Plant Microtechnique. McGraw Hill, New York.

LOWELl C. \& LUCANSKY T. W. 1986. Vegetative anatomy and morphology of Ipomoea hederifolia (Convolvulaceae). Bull. Torrey Bot. Club 113: 382-397.

LOWELl C. \& LuCANSKY T. W. 1990. Vegetative anatomy and morphology of Ipomoea quamoclit (Convolvulaceae). Bull. Torrey Bot. Club 117: 232-246.
McDonald A. 1992a. Taxonomic implications of normal and anomalous secondary growth in Ipomoea. In Abstracts: Amer. Inst. Biol. Sci. Publication 160.

McDonald J. A. 1992b. Evolutionary implications of typical and anomalous secondary growth in arborescent Ipomoea (Convolvulaceae). Bull. Torrey Bot. Club 119: 262-267.

Meira M., Silva E. P., David J. M. \& David J. P. 2012. Review of the genus Ipomoea: traditional uses, chemistry and biological activities. Braz. J. Pharm. 22: 682-713.

Metcalfe C. R. \& Chalk L. 1950. Anatomy of the dicotyledons. Clarendon Press, Oxford.

Mungole A. J., Awati R., Chaturvedi A. \& Zanwar P. 2010. Preliminary phytochemical screening of Ipomoea obscura (L) - A hepatoprotective medicinal plant. International Journal of Pharm Tech Research 2: 2307-2312.

Patil V. S., Rao K. S. \& Rajput K. S. 2009. Development of intraxylary phloem and internal cambium in Ipomoea hederifolia (Convolvulaceae). J. Torrey Bot. Soc. 136: 423-432.

Pfeiffer H. 1926. Das abnorme Dickenwachstum. Handbuch der Pflanzenanatomie. 9. Borntraeger, Berlin.

Prasad K. N., Divakar S., Shivamurthy G. R \& Aradhya S. M. 2005. Isolation of a free radical-scavenging antioxidant from water spinach (Ipomoea aquatica Forsk). Journal of the Science Food and Agriculture 85: 1461-1468.

Rajput K. S., Raole V. M. \& Gandhi D. 2008. Radial secondary growth, formation of successive cambia and their products in Ipomoea hederifolia L. (Convolvulaceae). Bot. J. Linn. Soc. 158: 30-40.

Rajput K. S., Nunes O. M., Brandes A. F. N. \& Tamaio N. 2012. Development of successive cambia and pattern of secondary growth in the stem of the Neotropical liana Rhynchosia phaseoloides (Sw.) DC. (Fabaceae). Flora 206: 607-614.

Singh V., SrivastaVa V. \& Sethi R. 2004. Ipomoea digitata seed gum and the gum-g-polyacrylamide: potential pharmaceutical gums. Pharmaceutical Biology 42: 230-233.

Terrazas T., Aguilar-Rodríguez S. \& Ojanguren C. T. 2011. Development of successive cambia, cambial activity, and their relationship to physiological traits in Ipomoea arborescens (Convolvulaceae) seedlings. Amer. J. Bot. 98: $765-774$.

Wheeler E. A., BaAs P. \& Gasson P. (eds) 1989. IAWA list of microscopic features for hardwood identification. I.A.W.A. Bull. 10: 219-332. 